Purdue University

Purdue e-Pubs

CESUN Conference

\title{
MAPPING OF THE INFORMATION FLOW OF THE VALLE OCCIDENTAL COFFEE REGION: A SYSTEM-OF-SYSTEMS PERSPECTIVE
}

Irene Campos

Purdue University

Follow this and additional works at: https://docs.lib.purdue.edu/cesun

Part of the Industrial Engineering Commons, and the Systems Engineering Commons

Campos, Irene, "MAPPING OF THE INFORMATION FLOW OF THE VALLE OCCIDENTAL COFFEE REGION: A SYSTEM-OF-SYSTEMS PERSPECTIVE" (2021). CESUN Conference. 7.

https://docs.lib.purdue.edu/cesun/cesun2020/papers/7

This document has been made available through Purdue e-Pubs, a service of the Purdue University Libraries.

Please contact epubs@purdue.edu for additional information. 


\title{
MAPPING OF THE INFORMATION FLOW OF THE VALLE OCCIDENTAL COFFEE REGION: A SYSTEM-OF-SYSTEMS PERSPECTIVE
}

\author{
Irene Campos Valle \\ Tecnológico de Costa Rica - Purdue University
}

\begin{abstract}
Uncertainty is a characteristic of many of the contemporary environments that our systems inhabit. In the case of farming systems, uncertainty has always been present in the form of unpredictable weather conditions, disease outbreaks and evolving societal and economic factors. Uncertainty poses a challenge for communication and information alignment, which is especially important for a farming system responding to disasters. A first step towards finding solutions for problems of information alignment in systems is mapping and identifying information links in them. The goal of this research is to map the information flow and feedback dynamics of the Valle Occidental coffee region in Costa Rica through a qualitative system-ofsystems study of this farming system.
\end{abstract}

\section{INTRODUCTION}

Farming and disaster response systems have in common that they exist within and in response to dynamic and uncontrollable physical environments. Systems Theory understands environment as all the variables that affect the system's state (Ackoff, 1971) and a characteristic of many contemporary environments is uncertainty (Emery \& Trist, 1965). In the case of farming systems, farmers have always had to deal with uncertainty from weather conditions and disease outbreaks, but farming environments have become increasingly complex and turbulent due to evolving societal and economic factors (Milestad, Dedieu, Darnhofer, \& Bellon, 2012). Something similar occurs in disaster response systems, where the uncertainty in the environment is manifested not only through the expected disruption caused by the disaster but also through the challenges in the interaction between organizations seeking to respond to the incident (Comfort, Sungu, Johnson, \& Dunn, 2001).

One of the main challenges involves communication, as it is known that the dynamic uncertainty of environments contributes to the complexity of communications within organizations (Caldwell, 2008). However, it is precisely the effective exchange of information between organizations with central responsibilities in disaster management that improves a region's capacity to reduce disaster risk (Comfort, Ko, \& Zagorecki, 2004). Moreover, research in disaster management has demonstrated that identifying the key nodes through which core information is exchanged is also crucial in improving interorganizational capacity for decision making (Comfort, Ko, \& Zagorecki, 2004). This confirms that knowing more about a system's composition, dynamics and interactions has practical benefits, to the point of saving lives and livelihood.

In recent years, research in farming systems has become more focused on studying how institutions, people and farming systems are fundamentally able to cope with change (Milestad, Dedieu, Darnhofer, \& Bellon, 2012). This is what is known as the adaptive approach, where the interest is not solely on farm productivity and yield maximization but in the farm's capacity to respond to challenges, such as disasters, as they arise (Milestad, Dedieu, Darnhofer, \& Bellon, 2012).
This shift was the result of the recognition that farms could not be studied as isolated units, but as members of a system comprised of interactions between objective components like soil, climatic conditions and infrastructure and subjective components like perceptions, values and preferences (Darnhofer, Gibbon, \& Dedieu, 2012). These farming systems were, at the same time, embedded in larger systems that provided context and meaning for decisions made within the farming system (Darnhofer, Gibbon, \& Dedieu, 2012). This would mean that interactions would not only occur at the same level, for example between two neighboring farms: but also, across levels, between farm clusters and national government organizations or between regional organizations and individual farms. The complexity of this composition makes information alignment and task coordination challenging for a farming system responding to environmental uncertainty, including natural disasters.

The aim of this paper is to approach the problem of information sharing in uncertainty through the mapping of information flow and feedback dynamics that are in place in the coffee producing industry of the Valle Occidental region in Costa Rica. Comprised mostly of small family farms, which in some cases are grouped in cooperatives, this coffee producing industry is an example of a highly collaborative system-ofsystems (SoS: see Literature Review below), with a long history of information coordination and expertise sharing between the private and public sectors. Despite this, little attention has been paid to the way this coordination occurs at different levels within the system-of-systems, for example, at an individual micro-farm level or at a farming region level like that of Valle Occidental. Questions about what type of information is relevant and what timescales would be needed for the information to remain relevant at these different units of analysis remain to be answered. A system-of-systems approach, thus, becomes an appropriate tool to identify the interactions at various levels that would enhance information sharing in the wake of a disaster.

\section{LITERATURE REVIEW}

\section{System of systems (SoS)}


The notion of a system of systems is not new; there have been numerous examples of systems comprised of multiple, independently operated systems that interact with each other, such as national transportation systems or the Internet (DeLaurentis, 2005). Early efforts in system-of-systems research were devoted to giving a definition to these known examples of systems. One of those definitions was proposed by Maier, who defined a system-of-systems (SoS) as an assemblage of components which individually may be regarded as systems and that have two key characteristics: operational and managerial independence (Maier, 1998). Once this was recognized, research in system-of-systems began to focus on devising appropriate taxonomies, lexicons and methods that would help resolve system-of-systems problems.

In the attempt to establish such taxonomies, Maier proposes three other traits that are important to differentiate a system-of-systems from other types of systems: geographical distribution, emergent behavior, and evolutionary development (Maier, 1996). Sage and Cuppan agree with these five characteristics and declare that for an SoS to be considered as such, all, or most of them, must be present (2001). Of these five, Meier argues that the crucial properties of a system of systems are that the components can and do operate independently. The reason for this is that a number of relevant and emerging systems do not count on centralized management for their development and operations. These systems are often naturally occurring, organically emerging and geographically distributed, and what makes them unique is their collaborative nature rather than guided structure. Such emergent and distributed systems are also called "collaborative systems" (Maier, 1998). It is important to note that in some literature a system-of-systems without a directed structure and centralized management is given the term Federation of Systems (FOS) (Krygiel, 1999). In addition to these five principles, in their study of applications of SoS for a healthcare system, Boustany and Caldwell expand on three additional traits: heterogeneity, network of networks and interdisciplinary nature (2007).

One aspect that is shared among most definitions, which is tightly linked to emergent behavior, is the notion that the purpose of the system-of-systems is not necessarily the purpose of the individual systems that compose it. An SoS carries out a purpose of its own, separate from those of the individual systems but achievable through the relationships between the constituent systems (Krygiel, 1999). The individual systems are operated for their own purposes rather than those of the bigger SoS and they can achieve these independent purposes even if detached from the overall system (Sage \& Cuppan, 2001). At the same time, they function to resolve issues of the bigger system that would be unachievable by the constituent systems acting independently (Sage \& Cuppan, 2001).

Despite the differences in terminology and characterization, research has converged into accepting and expanding Maier's principles for studying SoS (DeLaurentis, 2008). Given this precedent, eight characteristics of a systemof-systems are considered in this paper.

1. Operational independence of systems: If the system-of-systems is disassembled into its component systems the component systems must be able to usefully operate independently.

2. Managerial independence of systems: Component systems do operate independently.

3. Evolutionary development: Functions are added, removed, and modified over time.

4. Emergent behavior: The system performs functions and carries out purposes that do not reside in any component system. These behaviors are emergent properties of the entire system-of-systems and cannot be localized to any component system. The principal purposes of the systems-of-systems are fulfilled by these behaviors.

5. Geographic distribution: The system is usually distributed on a large geographic scale.

6. Heterogeneity: The elements of the system-ofsystems are different in nature.

7. Network of networks: Larger networks made up of smaller networks are found in the system.

8. Inter-disciplinary understanding: The analysis of the system requires unification of knowledge across different fields.

(Boustany \& Caldwell, 2007; Maier, 1996; Krygiel, 1999)

The acceptance of these traits was a successful step towards a better understanding of a system-of-systems. Other advances were made in the field to further classify a systemof-systems according to the nature of control in it, whether it be directed, virtual, collaborative, or acknowledged. (Maier, 1996; Dahmann \& Baldwin, 2008). These other classifications are outside the scope of this paper but serve to illustrate the efforts made in the field to better study system-of-systems problems.

In addition to the definition of characteristics, DeLaurentis proposed a lexicon to frame the SoS taxonomy (DeLaurentis, 2005). His lexicon is made up of two components: categories of systems and levels of organization. The categories highlight the heterogenous mix of engineered and sentient systems (composed of thinking and evolving agents), while the levels indicate hierarchy within the systemof-systems (DeLaurentis \& Callaway, 2004). This is also known as the ROPE model. 
Table 1. Categories and levels of SoS operations (from DeLaurentis, 2005)

\begin{tabular}{ll}
\hline Category & Description \\
\hline Resources & $\begin{array}{l}\text { The physical entities that give physical } \\
\text { manifestation to the system-of-systems }\end{array}$ \\
Operations & $\begin{array}{l}\text { The application of policies/procedures to } \\
\text { direct the activity of physical entities }\end{array}$ \\
Policies & $\begin{array}{l}\text { The external forcing functions that impact } \\
\text { the physical and nonphysical entities }\end{array}$ \\
Economics & $\begin{array}{l}\text { The nonphysical, sentient systems that } \\
\text { give a "living system" character to the }\end{array}$ \\
& $\begin{array}{l}\text { operation of the physical entities in a } \\
\text { market economy }\end{array}$ \\
\hline Level & Description \\
Blpha $(\alpha)$ & $\begin{array}{l}\text { Base level of entities in each category, } \\
\text { further decomposition will not take place }\end{array}$ \\
Collections of $\alpha$-level systems (across \\
categories), organized in a network \\
Collections of $\beta$-level systems (across \\
Delta $(\delta)$
\end{tabular}

An advantage of DeLaurentis' lexicon is the fact that by using Greek letters, it avoids confusion when establishing hierarchy, as the letters indicate the position within the overall system. In other words, the smallest component systems of the SoS would be at the Alpha $(\alpha)$ level, the network of those small systems would create the next "system-of-systems" at the Beta $(\beta)$ level and this would continue. This is another advantage of this model: the possibility to accommodate the lexicon to the size of the system-of-systems in study.

This lexicon has been applied to system-of-system problems in the areas of healthcare (Boustany \& Caldwell, 2007) and transportation (DeLaurentis \& Callaway, 2004) demonstrating its adaptability and effectiveness in representing the SoS across a range of environmental, organizational, social and technological contexts.

\section{Information alignment}

Alignment has been defined as the proper position or adjustment of resources in relation to each other (Palmer, 2007). Often this has been framed within the context of organizations, specifically in terms of performance, process, scheduling, and information adjustment across the organizational structure. When considered in terms of system dynamics, some perspectives point out that alignment is a design characteristic of a system, whereas others argue that it is a dynamic condition of a system (Caldwell, 2013). In other words, according to the latter view, alignment is not a static "how-it-should-be" attribute of a system but rather an evolving "how-it-is" condition of a system.

Of the types of alignment mentioned before, information alignment is said to be essential to knowledge of the system's state. The reason for this is that information alignment spans all areas of operation and decision making within the system, offering a representation of the system's condition (Palmer \&
Caldwell, 2009). If the definition of alignment presented previously is considered, then information alignment would be the way to know whether the state of the system is that of alignment in other dimensions as well.

Whenever there is misalignment of information, the system can be inaccurately perceived, and decisions made under these conditions can leave the system vulnerable to errors that may evolve into adverse events (Palmer, 2007). In the case of teams in distributed settings, like those working in disaster response, poor decision-making and failures in information flow can be minimized by proper information alignment and coordination (Caldwell, Palmer, \& Cuevas, 2013). The cost of information misalignment in critical, lifeor-death settings, like emergency response are high at a societal level (Caldwell, 2013). Studies of breakdowns in emergency response coordination have shown failures to anticipate and update the effect of changing conditions on the availability, robustness, or sustainability of information services (Caldwell, 2013).

One way in which these problems of information misalignment can be solved is through an effective mapping of the information flow dynamics of a system. Research in information exchange during crisis operations has demonstrated that, unless the communication system is physically destroyed, information is accumulated and shared through a "small-world" network (Comfort, Ko, \& Zagorecki, 2004). A "small-world" network is one in which there is a small average distance between nodes and at the same time high clustering between them. An example that is often used to explain such interactions is naturally occurring interpersonal friendships in a community, where people seek to make connections intentionally, creating clusters of friends, while at the same time each person is only five or six people away from anyone else (Telesford, Joyce, Hayasaka, Burdette, \& Laurienti, 2011). Research points out that identifying these networks among organizations in regions exposed to disaster risk would represent a critical advance to improving capacity for interorganizational decision support in disaster management (Comfort, Ko, \& Zagorecki, 2004).

\section{The coffee industry in Costa Rica}

The high value attached to efficient and top-quality coffee production makes the operation and robustness of the coffee industry a priority in Costa Rica. Coffee is Costa Rica's third largest agricultural export, but more important than its contribution to economic growth is its contribution to the country's economic development. The revenue generated by the initial coffee export "boom" in the mid-nineteenth century fueled the country's investment in infrastructure, banking, communication, and education systems (Canet, 1993). In recent years, coffee has also served to democratize the land, since most of the production is in the hands of small, independent producers with agency over their farming practices and revenues. In addition, being a labor-intensive activity, especially during harvest season, coffee production has become a steady source of jobs for both locals and immigrants from Nicaragua and Panama (ICAFE, 2019). 
Since the beginning of the twentieth century, there was interest from Costa Rican governments to protect and promote coffee production through government action (Canet, 1993). Government intervention in the industry saw its peak in 1961 with the promotion of a national "Coffee Law", aimed at regulating the economic relations between coffee producers, millers, roasters, and exporters. By 1985, the Costa Rica Institute of Coffee (ICAFE) was designated as the office in charge of this task (Canet, 1993). The law defines coffee producers as those who have the rights and obligations to profit from a coffee plantation and millers as those who, owning a mill, would receive, process, and sell beans (Ley 2762: Régimen Relaciones de Productores, Beneficiadores y Exportadores Café, 2011). The idea behind the law was to guarantee fair relations between all actors in the chain. The ICAFE was to accomplish this through price regulation, control and registration of producers, millers and yields, promotion of the industry, and technology transfer. To perform these operations the ICAFE delegated activities to each of its eight regional offices (ICAFE, 2015).

The Valle Occidental region is the second largest coffee growing region in Costa Rica both in size and net exports (ICAFE, 2019). According to the Ministry of Agriculture (MAG), this is a region characterized by a high degree of land distribution and a relatively small average farm size (MAG, 2015). The environmental conditions of Valle Occidental also make it suitable for agricultural practices, especially coffee: altitudes are appropriate, soils are highly fertile due to their volcanic origin; temperatures are stable all year round and seasons are well defined. Coffee production is in part responsible for the high-income distribution and social equality of the region (ICAFE, 2015).

\section{ANALYSIS}

\section{Complexity of the coffee production farming system}

The general stability of the Valle Occidental region mentioned in the previous section does not account for variations in environmental conditions between farms. Natural factors such as precipitation, altitude, and soil acidity can change considerably over short distances, which is why coffee from this region is considered specialty coffee; in a way, each farm produces its own variety of coffee (Solís, 2020). The altitude range in the region goes from 800 meters to 1400 meters above sea level and differences in acidity can be of up to one $\mathrm{pH}$. Other coffee regions in Costa Rica, like Tarrazu, do not present this degree of variation (ICAFE, 2011). Environmental differences pose a challenge to the specificity of the information that is collected, analyzed, and distributed to farmers.

The Costa Rican coffee producing industry in the Valle Occidental region is comprised of small "micro-farms" of about 3 hectares each (Rojas M., 2020). Farms are independently owned and operated. Some producers sell the fruit to cooperatives or private mills; others have their own micro-mills and process the fruit themselves to later sell to roasters both in Costa Rica and abroad. Others also roast their own coffee and sell it directly in local and foreign markets. In the region, the cooperative model is strong but not exclusive; although most producers are associated to them, not all are (Fonseca, 2020; Quesada, 2020).

Information sharing within the system is conditioned by several factors. One of them is technological literacy. Seven out of ten coffee producers are over 58 years old and although most have access to smart mobile devices and some forms of social media, it is not common that they use digital tools for operative tasks (Castro, 2020; Rojas V., 2020). Efforts have been made by ICAFE to provide farmers with digital tools, such as apps, that would help coffee producers to register and manage information more efficiently, but these are recent and still not widespread (Rojas V., 2020). Many farmers continue to prefer communication through in person conversations, since "everyone knows everyone" in the industry and relations are built on trust (Solís, 2020; Quesada, 2020). The need for generational integration is well known in the system. Traders and clients, who are not necessarily part of the coffee growing system but interact with it, have noticed that younger generations, mainly the farmers' sons and daughters, are returning to the farms and bringing with them new managerial and communication practices that often involve digital mediums, especially social media (Leiva, 2020).

Another challenge for communication and information alignment has to do with changes in the sources of technical information. When the Coffee Law was conceived, the Ministry of Agriculture and ICAFE were the main providers of technical assistance to farmers. Both institutions had robust teams of agricultural engineers and technicians that advised farmers on farming practices (Vargas, 2020). These teams were not in competition but coordinated to cover as many farms as possible. However, in the last few years more and more farmers began to seek technical assistance from private mills, cooperatives and even agrochemical providers (Fonseca, 2020; Vargas, 2020; Castro, 2020). Some argue that reduced budgets for technology transfer in the agricultural sector forced government institutions to downsize their teams and farmers had to look elsewhere, but others point out that because regulation limited private mills from competing in price they had to allure coffee producers with alternative incentives like providing technical assistance in the field (Fonseca, 2020; Vargas, 2020). Whatever the reason, the underlying result was that new information pathways emerged in the system.

It is in this dynamic and evolving context that emergency response coordination for the Valle Occidental region takes place. In Costa Rica, disaster response and mitigation operations are coordinated by the central government through the National Emergency Commission (CNE). The CNE has a well-established communication network that includes all ministries or departments of government, first responders, local governments, and others. 


\section{SoS Lexicon and ROPE model for the Valle Occidental coffee region}

The role that government institutions play in the coffee producing system raises questions about the nature of the system. Are these institutions part of the system themselves or are they only interacting with it? When they interact, do they do it directly with individual farmers or through ICAFE? Furthermore, how does the fact that micro-farms are in themselves systems with inputs, outputs, operations, and interactions affect the delimitation of the system? The answers lie in the distinction between the purpose of individual microfarms, which is to grow coffee for livelihood, and the purpose of the coffee region which is to ensure the conditions for coffee production. Nonetheless, both are part of the overall coffee producing system. From this observation, it can be stated that the coffee growing industry in the Valle Occidental region qualifies as a system-of-systems that obeys the fundamental guidelines to be called as such:

1. Operational independence of systems: Each microfarm can perform its main purpose of cultivating and harvesting coffee beans without the intervention of other components of the system.

2. Managerial independence of systems: Each microfarm is managed independently according to the will and capabilities of its owner.

3. Evolutionary development: The system and its subsystems have seen changes in its functions over time; for example, more producers milling and even roasting their fruit instead of selling to mills or farms diversifying through touristic coffee tours.

4. Emergent behavior: The coordination of the coffee production system transcends the properties and capabilities of each of the sub-systems.

5. Geographic distribution: The coffee growing system is distributed along a geographical region of 23000 hectares.

6. Heterogeneity: Farms in the same region are very different from each other, depending on a variety of factors like changes in altitude, differences in shade and precipitation or managerial styles.

7. Network of networks: Neighboring farms are connected by proximity and social relations, creating a network. These networks interact with others at the same level and at different levels.

8. Inter-disciplinary understanding: The analysis of the system requires unification of knowledge across different fields, especially system dynamics, economics, and agronomy.

If the SoS lexicon is applied, micro-farms occupy the $\alpha$ level. These are the most fundamental units of the system-ofsystems. In Valle Occidental, there were 9383 registered producers for the 2018-2019 harvest (Rojas M., 2020). At a $\beta$ level there would be clusters of micro-farms; these clusters could be formal in the form of cooperatives and private farmers' associations or informal, for example neighboring farms that share labor during harvest season. Mills would also be part of the $\beta$-level, but only if they receive fruit from different farms, individual farms that operate their own "micro-mill" would do so at an $\alpha$-level. In Valle Occidental there are 55 private mills, 4 cooperatives and 1 private farmers association (Rojas M. , 2020). The $\gamma$-level would be made up of the network of clusters, associations and cooperatives that make up a coffee region as well as regional government offices that interact with them. The coffee industry of the Valle Occidental region would be an example of the $\gamma$-level [see Figure 1]. This level is already a system-of-systems but even the Valle Occidental coffee producing region is embedded in a national coffee producing system. The national level would be the $\delta$-level of the system-of-systems.

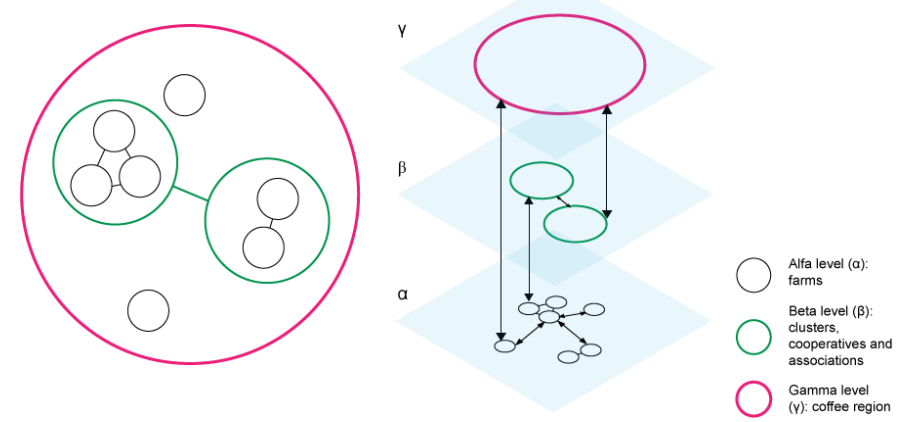

Figure 1. The coffee production industry as a system-ofsystems

The horizontal and vertical interaction of systems in the system-of-systems structure points out to the reality that embedded systems interact with systems on their level as well as with systems in other levels. For example, an individual farm interacts with neighboring farms but could also interact with the MAG regional office at the $\gamma$-level; similarly, the ICAFE regional office interacts with cooperatives and associations but could also interact with an individual farm from that cooperative. The fact that no system, and especially no farming system, is isolated from an economic and political dimension implies that SoS problem solving must take into consideration the way in which these dimensions relate to the system (see Table 1; see also Appendix 1). 
Table 2. Summarized ROPE model for the Valle Occidental coffee region

\begin{tabular}{|c|c|c|c|c|}
\hline & Resources & Operations & Policies & Economics \\
\hline $\begin{array}{l}\alpha- \\
\text { level }\end{array}$ & $\begin{array}{l}\text { Farms } \\
\text { (called } \\
\text { micro- } \\
\text { farms) }\end{array}$ & $\begin{array}{l}\text { Harvest, } \\
\text { prune, hire, } \\
\text { pay, plan } \\
\text { production }\end{array}$ & $\begin{array}{l}\text { Registration } \\
\text { of producers } \\
\text { and seasonal } \\
\text { migrant } \\
\text { workers }\end{array}$ & $\begin{array}{l}\text { Farming } \\
\text { costs, profit, } \\
\text { investment } \\
\text { capital }\end{array}$ \\
\hline $\begin{array}{l}\beta- \\
\text { level }\end{array}$ & $\begin{array}{l}\text { Farm } \\
\text { clusters, } \\
\text { cooperative } \\
\text { s, private } \\
\text { associations } \\
\text {, private } \\
\text { mills, } \\
\text { agrochemic } \\
\text { al suppliers }\end{array}$ & $\begin{array}{l}\text { Mill and roast } \\
\text { coffee, } \\
\text { coordinate } \\
\text { workforce } \\
\text { allocation, } \\
\text { communicatio } \\
\mathrm{n} \text { with } \\
\text { associated } \\
\text { farmers }\end{array}$ & $\begin{array}{l}\text { Mill } \\
\text { regulation } \\
\text { and } \\
\text { inspection, } \\
\text { volume } \\
\text { (fruit) to } \\
\text { weight } \\
\text { (bean) ratio } \\
\text { regulation, } \\
\text { timeframe } \\
\text { to deliver } \\
\text { fruit to mills } \\
\end{array}$ & $\begin{array}{l}\text { Subsidies in } \\
\text { the form of } \\
\text { technical } \\
\text { assistance, } \\
\text { competition } \\
\text { between } \\
\text { mills }\end{array}$ \\
\hline $\begin{array}{l}\gamma- \\
\text { level }\end{array}$ & $\begin{array}{l}\text { Valle } \\
\text { Occidental } \\
\text { farming } \\
\text { region, } \\
\text { regional } \\
\text { government } \\
\text { offices }\end{array}$ & $\begin{array}{l}\text { Coordinate } \\
\text { information } \\
\text { sharing in } \\
\text { region, } \\
\text { inspect farm } \\
\text { and mills, } \\
\text { coordinate } \\
\text { regional } \\
\text { disaster } \\
\text { response } \\
\text { activities }\end{array}$ & $\begin{array}{l}\text { Training } \\
\text { and } \\
\text { education } \\
\text { policies for } \\
\text { the region, } \\
\text { regional } \\
\text { emergency } \\
\text { response } \\
\text { plan, } \\
\text { assignment } \\
\text { of regional } \\
\text { health care } \\
\text { center for } \\
\text { seasonal } \\
\text { migrant } \\
\text { workers }\end{array}$ & $\begin{array}{l}\text { Price } \\
\text { regulation, } \\
\text { regional } \\
\text { government } \\
\text { budget for } \\
\text { coffee } \\
\text { industry }\end{array}$ \\
\hline $\begin{array}{l}\delta- \\
\text { level }\end{array}$ & $\begin{array}{l}\text { Network of } \\
\text { farming } \\
\text { regions at a } \\
\text { national } \\
\text { level }\end{array}$ & $\begin{array}{l}\text { National } \\
\text { coffee } \\
\text { production } \\
\text { coordination, } \\
\text { national } \\
\text { emergency } \\
\text { coordination }\end{array}$ & $\begin{array}{l}\text { National } \\
\text { coffee law, } \\
\text { alliance } \\
\text { with health } \\
\text { care } \\
\text { services to } \\
\text { provide } \\
\text { health care } \\
\text { to seasonal } \\
\text { workers }\end{array}$ & $\begin{array}{l}\text { National } \\
\text { coffee } \\
\text { market } \\
\text { trends, costs } \\
\text { of health } \\
\text { care for } \\
\text { migrant } \\
\text { seasonal } \\
\text { workers }\end{array}$ \\
\hline
\end{tabular}

The advantage of applying the SoS lexicon and ROPE model for this case is that both show that grain sizes affect the dynamics of the system. A national policy like health care coverage for seasonal migrant workers might be designed at a $\delta$-level but its enforcement will look different at the $\gamma$-level and $\alpha$-level. In a similar way, the timescales, type of information and flow that is needed to respond to a disaster will depend on the level of the system-of-systems.

\section{Information sharing in the Valle Occidental coffee region}

As mentioned above, the complexity in information sharing in the Valle Occidental region is multicausal. The diversification of sources for technical information has debilitated some of the ties that existed between producers and the public sector. In the day-to-day reality, this mostly affects information alignment in technology transfer, but it could also impact alignment in non-routine activities like disaster response coordination in time-critical conditions.

Disaster response activities that take place in coffee regions are planned at a national, $\delta$-level, but are executed at a $\gamma$-level, through the joint effort of regional offices, local governments and first responders. However, according to officials, ICAFE is not part of the CNE's robust communication network and interaction between the two institutions is sporadic (see Figure 2) (Fonseca, 2020). On the other hand, relations between the Ministry of Agriculture and ICAFE are strong at the $\delta$-level, as the Ministry of Agriculture holds a seat at the ICAFE Board of Directors. At the $\gamma$-level, both institutions have regional divisions, but these are different and not always aligned, which affects coordination and communication (Fonseca, 2020). For example, the MAG region that includes ICAFE's Valle Occidental region, also includes parts of ICAFE's Central region. To address this, the institutions have created a regional committee, coordinated by ICAFE's Valle Occidental office, with the purpose of aligning information between offices for the specific needs of Valle Occidental (Ruiz, 2020). In practice, communication with clusters at the $\beta$-level and farmers at the $\alpha$-level remains a task of the separate offices, with MAG more focused on microfarms and ICAFE on cooperatives and associations as well as some individual micro-farms.
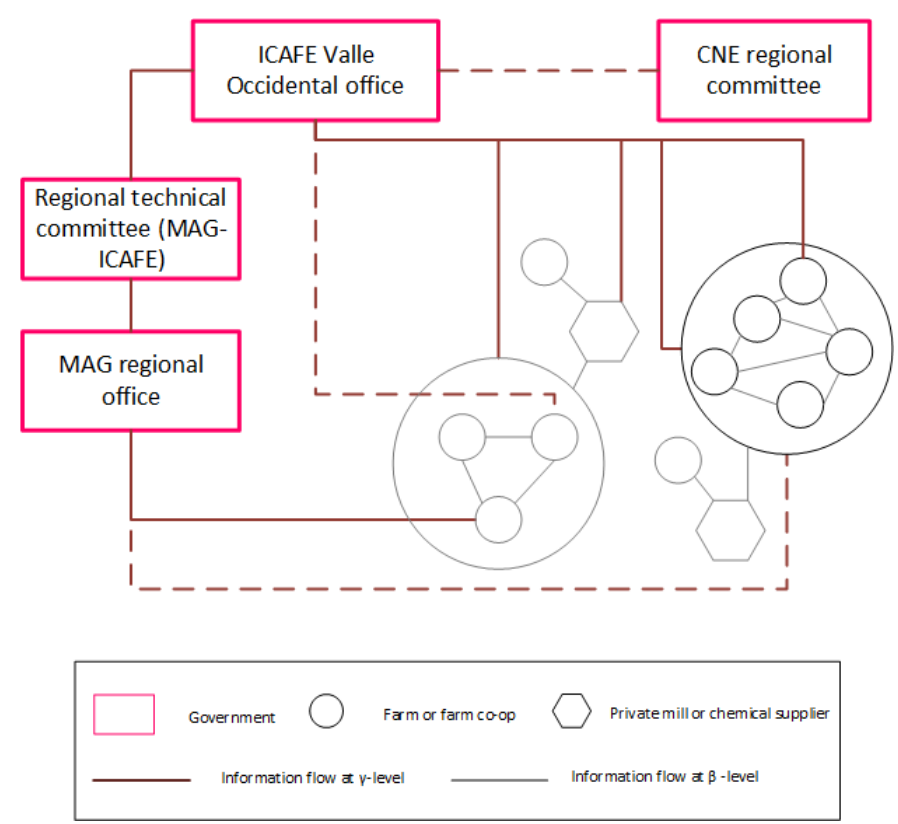

Figure 2. Information flow for disaster response at the $\gamma$-level

Information flow, at a $\gamma$-level, between ICAFE regional offices and farms depends on the willingness of the producer or cooperative to establish a link. For example, mass group messaging between farmers and ICAFE officials is the most common way of communicating but it is only effective when the producer has ICAFE as one of its contacts (Rojas M., 2020; Solís, 2020). Coffee producers that are not part of these group chats are not necessarily isolated, some create their alternative communication networks, even in person ones, with neighbors, seasonal workers and private mills or 
suppliers (Quesada, 2020). At a $\delta$-level, information regarding weather forecasts and disease outbreaks is available through social media and ICAFE's website but alignment also depends on factors like the farmer's interest and technology literacy. Cultural factors like tradition and a passive mindset when it comes to information foraging hinder information alignment as well (Fonseca, 2020).

\section{CONCLUSIONS}

The Valle Occidental coffee region of Costa Rica is an example of a system-of-systems at a $\gamma$-level. In it, networks of systems at different levels can and do operate independently and out of their interactions new properties emerge. With time, the SoS has also evolved, especially in constructing new information pathways and diversifying its economic activities. The fact that there is regulation does not change its classification as a system-of-systems, as regulation is also seen in other SoS like a transportation networks or the Internet.

An SoS representation of the Valle Occidental coffee region is useful for decision makers that seek to improve information alignment. From the breaking down the system in its components and levels, it is clear that information sharing in the system looks different depending on the grain size. As ICAFE works to develop tools for better technology transfer, aspects like the informal networks that producers create at the $\alpha$-level or the close relations between farmers and technicians from agrochemical suppliers at the $\beta$-level have to be taken into consideration. The fact that farmers and millers must be registered at the ICAFE regional offices is an advantage for information alignment, but it currently does not guarantee that communication takes place. There are examples of farmers that prefer technical assistance from other sources and those who are skeptical of regulation. As regional government offices plan their strategies regarding disaster response, to understand the region as a system-of-systems helps to identify those "small-world" networks through which key information is passed, the level in which they operate and how they interact with networks in other levels.

As far as information sharing between public institutions, the SoS representation proposed in this paper sheds light into strengths and weaknesses in their alignment. Communication between institutions is strongest at the $\delta$-level, where public policy is designed. At this level, ICAFE and MAG have a solid communication pathway through ICAFE's Board of Directors. At the $\gamma$-level, through tasks associated to the regional technical committee, both regional offices are connected; however, the differences in regional divisions in both institutions mean that MAG has to perform additional tasks of internal alignment before sharing with ICAFE. Another weakness in alignment has to do with disaster response in the Valle Occidental region, since few pathways exist between ICAFE's regional offices and the National Emergency Commission. CNE does not participate of the regional technical committee and its link to the region occurs through local governments, whereas ICAFE's main link to the region is directly through farms and cooperatives. In other words, the Valle Occidental coffee region, as a system-ofsystems, has established information pathways, both formal and informal, but these do not include the CNE. Additional work could be done to compare the description of the state of the system proposed in this research with the designed disaster response information network. This could improve information alignment for the overall farming system, enhancing its capacity to withstand uncertainty from the environment.

Information alignment in the region will become more complex with the societal and economic changes that the industry is undergoing. New farming styles brought by younger generations, the producers' desire to process their own coffee beans in their micro-mills instead of partnering with private mills, the possibility to access technology from other sources plus environmental changes will challenge the status quo of the system. This paper offers a first step into a qualitative understanding of the current system dynamics, but it is important to note that the complex nature of these systems made up of systems means that conditions can and will change in the future. Nonetheless, the categorization presented here is valuable and can help to effectively guide a more quantitative study in the future, one that could include modeling and simulation of information flow in this system-of-systems.

\section{REFERENCES}

Ackoff, R. L. (1971). Towards a system of systems concepts. Management Science, 17(11), 661-671. Retrieved from

https://ackoffcenter.blogs.com/ackoff_center_weblog /files/AckoffSystemOfSystems.pdf

Boustany, K. C., \& Caldwell, B. S. (2007). Information and Resource Coordination in Healthcare Providers. Proceedings of the 2007 Industrial Engineering Research Conference.

Caldwell, B. S. (2008). Knowledge sharing and expertise coordination of event response in organizations. Applied Ergonomics, 39(4), 427-438.

Caldwell, B. S. (2013). Improving information alignment and dynamic allocation of IT functions. Proceedings of the 2013 Industrial and Systems Engineering Research Conference.

Caldwell, B. S., Palmer, R. C., \& Cuevas, H. M. (2013). Information Alignment and Task Coordination in Organizations: Information Systems Management, 33-44.

Canet, G. (1993). Evolución de la caficultura costarricense y situación actual de la actividad: enfoque a nivel nacional y mundial [Evolution and current state of the Costa Rican coffee culture: a national and international approach]. IX Congreso nacional agropecuario y de recursos naturales. San José.

Castro, M. (2020, May 20). Interview with ICAFE board member and coffee producer. (I. Campos Valle, Interviewer)

Comfort, L. K., Ko, K., \& Zagorecki, A. (2004). Coordination in Rapidly Evolving Disaster Response Systems: The 
Role of Information. American Behavioral Scientist, 48(3), 295-313.

Comfort, L. K., Sungu, Y., Johnson, D., \& Dunn, M. (2001). Emergency decision making for natural disasters: An overview. Emergency decision making for natural disasters: An overview, 9(3), 144-158.

Dahmann, J. S., \& Baldwin, K. J. (2008). Understanding the Current State of US Defense Systems of Systems and the Implications for Systems Engineering. 2008 2nd Annual IEEE Systems Conference, (pp. 1-7). Montreal, Quebec.

Darnhofer, I., Gibbon, D., \& Dedieu, B. (2012). Farming Systems Research: an approach to inquiry. In Farming Systems Research into the 21st Century: The New Dynamic (pp. 3-32). Springer. doi:10.1007/978-94-007-4503-2_1

DeLaurentis, D. A. (2005). A taxonomy-based perspective for systems of systems design methods. 2005 IEEE International Conference on Systems, Man and Cybernetics, 1, pp. 86-91. Waikoloa, HI.

DeLaurentis, D. A. (2008). Appropriate modeling and analysis for systems of systems: Case study synopses using a taxonomy. 2008 IEEE International Conference on System of Systems Engineering, (pp. 1-6). Singapore.

DeLaurentis, D. A., \& Callaway, R. K. (2004). A System-of-Systems Perspective for Public Policy Decisions. Review of Policy Research, 21(6), 829837.

Emery, F. E., \& Trist, E. L. (1965). The causal texture of organizational environments. Human Relations, 18, 21-32.

Fonseca, C. (2020, May 26). Interview with Technical Unit Manager at ICAFE. (I. Campos Valle, Interviewer)

ICAFE. (2011). Caracterización de la fertilidad de suelos cafetaleros de Costa Rica [Characterization of soil fertility for coffee plantations in Costa Rica]. Retrieved from ICAFE website: https://sig.icafe.cr/caracterizacion.html

ICAFE. (2015, March). Nuestro café: regiones cafetaleras [Our coffee: coffee regions]. Retrieved from ICAFE website: http://www.icafe.cr/nuestro-cafe/regionescafetaleras/valle-occidental/

ICAFE. (2019). Informe sobre la actividad cafetalera de Costa Rica [Report on coffee activities in Costa Rica]. Heredia. Retrieved from http://www.icafe.cr/sector-cafetalero/informacion-demercado/informes-de-la-actividad-cafetalera/

Krygiel, A. J. (1999). Systems of systems and federations of systems. In A. J. Krygiel, Behind the wizard's curtain: an integration environment for a system of systems (pp. 31-48). National Defense University.

Leiva, A. (2020, April 02). Interview with coffee trader and Sintercafe president. (I. Campos Valle, Interviewer)

Ley 2762: Régimen Relaciones de Productores, Beneficiadores y Exportadores Café [Law 2762: Relations between coffee producers, millers and exporters]. (2011, november 27). Asamblea legislativa. San José, Costa Rica. Retrieved from http://www.pgrweb.go.cr/scij/Busqueda/Normativa/N
ormas/nrm_texto_completo.aspx?param1=NRTC\&n Valor1=1\&nValor2=36867\&nValor3=38867\&strTip $\mathrm{M}=\mathrm{TC}$

MAG. (2015). Análisis del contexto de la región [Regional context analysis]. San José. Retrieved from http://www.mag.go.cr/regiones/centraloccidental.htm 1

Maier, M. W. (1996). Architecting principles for systems-of-systems. INCOSE International Symposium, (pp. 565-573). Boston, MA. doi:doi:10.1002/j.2334-5837.1996.tb02054.x

Maier, M. W. (1998). Architecting principles for systems-of-systems. Systems engineering: the journal of the international council on systems engineering, 1(4), 267-284.

Milestad, R., Dedieu, B., Darnhofer, I., \& Bellon, S. (2012). Farms and farmers facing change: the adaptive approach. In Farming Systems Research into the 21st Century: The New Dynamic (pp. 365-386). Springer.

Palmer, R. (2007). Assessing Information Alignment in Production Organizations. Proceedings of the human factors and ergonomics society 51st annual meeting, 51(16), 981-985. Retrieved from https://journals.sagepub.com/doi/abs/10.1177/154193 120705101604?casa_token=tTU7MnfbJ4QAAAAA:t 1pWZoqxEi1EVPUGMRrMfrN6bNBxYMHMkIimn VgC47K6T84wcGo3brjR_WSaCU8ijjSJotGqj9sjw\#articleCitationDownloadContainer

Palmer, R., \& Caldwell, B. (2009). Improving computermediated information alignment. Journal of Intelligent Manufacturing, 22(1), 89-99.

Quesada, A. (2020, March 03). Interview with coffee producer in the Valle Occidental region. (I. Campos Valle, Interviewer)

Rojas, M. (2020, April 14). Interview with ICAFE Valle Occidental regional manager. (I. Campos Valle, Interviewer)

Rojas, V. (2020, April 20). Interview with Technology Transfer Manager at ICAFE. (I. Campos Valle, Interviewer)

Ruiz, J. (2020, June 03). Interview with MAG coffee coordinator. (I. Campos, Interviewer)

Sage, A. P., \& Cuppan, C. D. (2001). On the systems engineering and management of systems of systems and federations of systems. Information, Knowledge, Systems Management, 225-245.

Solís, H. (2020, March 24). Interview with coffee producer in Valle Occidental region. (I. Campos Valle, Interviewer)

Telesford, Q., Joyce, K. E., Hayasaka, S., Burdette, J. H., \& Laurienti, P. (2011). The ubiquity of small-world networks. Brain Connectivity, 1(5), 367-375.

Vargas, P. (2020, May 27). Interview with Britt Group chairman and former agricultural economics profesor at UCR. (I. Campos Valle, Interviewer) 


\section{APPENDIX}

Appendix 1. ROPE Model for Valle Occidental coffee region

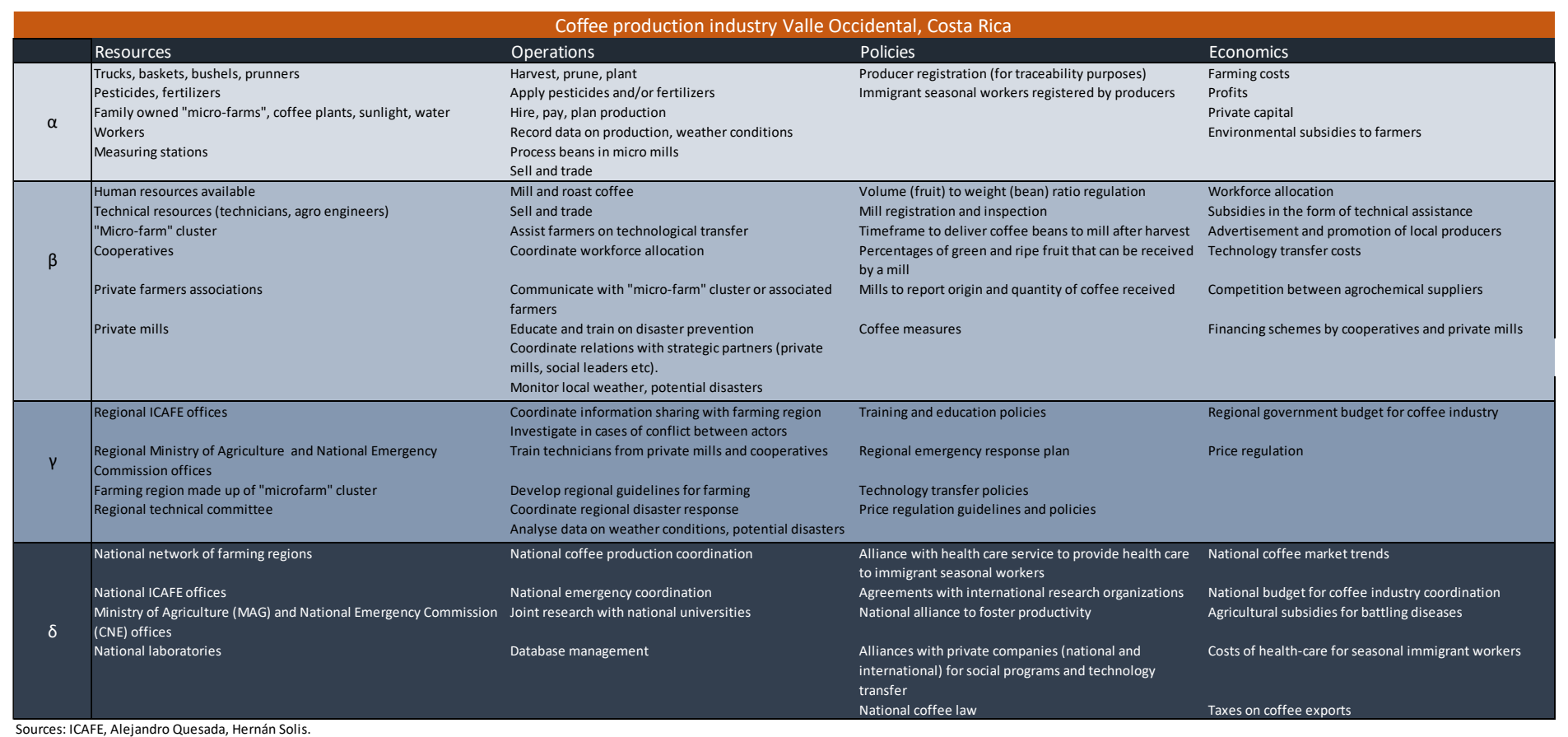

